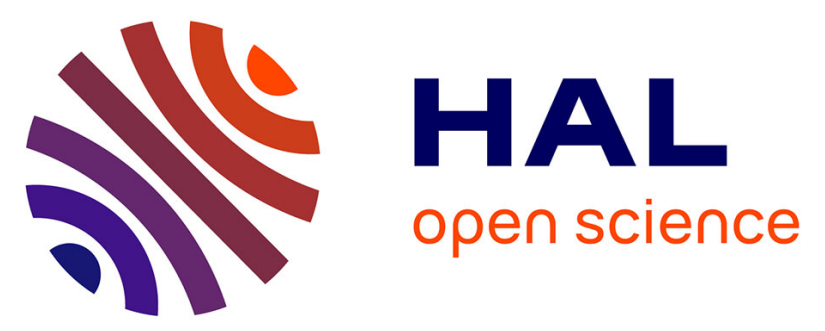

\title{
Tuning the Photoelectrocatalytic Hydrogen Evolution of Pt-Decorated Silicon Photocathodes by the Temperature and Time of Electroless Pt Deposition
}

\author{
Bruno Fabre, Li Gaozeng, F. Gouttefangeas, L. Joanny, Gabriel Loget
}

\section{- To cite this version:}

Bruno Fabre, Li Gaozeng, F. Gouttefangeas, L. Joanny, Gabriel Loget. Tuning the Photoelectrocatalytic Hydrogen Evolution of Pt-Decorated Silicon Photocathodes by the Temperature and Time of Electroless Pt Deposition. Langmuir, 2016, 32 (45), pp.11728-11735. 10.1021/acs.langmuir.6b02122 . hal-01416454

HAL Id: hal-01416454

https://hal-univ-rennes1.archives-ouvertes.fr/hal-01416454

Submitted on 13 Jul 2017

HAL is a multi-disciplinary open access archive for the deposit and dissemination of scientific research documents, whether they are published or not. The documents may come from teaching and research institutions in France or abroad, or from public or private research centers.
L'archive ouverte pluridisciplinaire HAL, est destinée au dépôt et à la diffusion de documents scientifiques de niveau recherche, publiés ou non, émanant des établissements d'enseignement et de recherche français ou étrangers, des laboratoires publics ou privés. 


\title{
Tuning the Photoelectrocatalytic Hydrogen
}

\section{Evolution of Pt-decorated Silicon Photocathodes}

\section{by Pt Electroless Deposition Temperature and}

\author{
Time \\ Bruno Fabre $^{a}$, Li Gaozeng $^{a}$, Francis Gouttefangeas ${ }^{b}$, Loic Joanny ${ }^{b}$ and Gabriel Loget $^{a, *}$ \\ a Institut des Sciences Chimiques de Rennes (ISCR), UMR 6226 CNRS/Université de Rennes \\ 1, Matière Condensée et Systèmes Electroactifs (MaCSE), Campus de Beaulieu, 35042 \\ Rennes Cedex, France \\ ${ }^{\mathrm{b}}$ ScanMAT - CMEBA, Université de Rennes 1, Campus de Beaulieu, 35042 Rennes Cedex, \\ France
}

KEYWORDS. Hydrogen evolution reaction; Hydrogen-terminated silicon; Electroless metal deposition; Photocathodes; Photoelectrocatalysis

\begin{abstract}
The electroless deposition of Pt nanoparticles (NPs) on hydrogen-terminated silicon $(\mathrm{H}-\mathrm{Si})$ surfaces is studied as a function of temperature and the immersion time. It is demonstrated that isolated Pt structures can be produced at all investigated temperatures (between 22 and $75^{\circ} \mathrm{C}$ ) for short deposition times, typically within 1-10 min if the temperature was $45^{\circ} \mathrm{C}$ or less than $5 \mathrm{~min}$ at $75^{\circ} \mathrm{C}$. For longer times, dendritic metal structures
\end{abstract}


start to grow leading ultimately to highly rough interconnected Pt networks. Upon increasing temperature from 22 to $75^{\circ} \mathrm{C}$ and for an immersion time of $5 \mathrm{~min}$, the average size of the observed Pt NPs monotonously increases from 120 to $250 \mathrm{~nm}$ and their number density calculated by scanning electron microscopy decreases from $(4.5 \pm 1.0) \times 10^{8}$ to $(2.0 \pm 0.5) \times$ $10^{8} \mathrm{Pt}$ NPs $\mathrm{cm}^{-2}$. The impact of both the morphology and distribution of Pt nanoparticles on the photoelectrocatalytic activity of the resulting metallized photocathodes is then analyzed. Pt deposited at $45^{\circ} \mathrm{C}$ for 5 min yields photocathodes with the best electrocatalytic activity for the hydrogen evolution reaction (HER). Under illumination at $33 \mathrm{~mW} \mathrm{~cm}^{-2}$, this optimized photoelectrode shows a fill factor $(F F)$ of $45 \%$, an efficiency $(\eta)$ of $9.7 \%$ and a short-circuit current density $\left(\left|J_{\mathrm{sc}}\right|\right)$ at $0 \mathrm{~V} v s$ reversible hydrogen electrode (RHE) of $15.5 \mathrm{~mA} \mathrm{~cm}^{-2}$.

1. Introduction. The conversion of sunlight into clean and storable fuels is very appealing in the frame of the actual growing need for sustainable sources of energies. To this end, the use of solar-driven electrochemical cells that can split water into hydrogen and oxygen seems a very promising technology. ${ }^{1,2,3}$ Nevertheless, the fabrication of stable, low-cost and really efficient photoelectrodes is still a harsh challenge in this thematic area. ${ }^{4,5,6,7}$ Silicon, with a gap energy of $1.12 \mathrm{eV},{ }^{8}$ is a very promising material to be used as a photocathode material for hydrogen evolution reaction (HER) because of its abundance, non-toxicity and its tunable electronic properties. ${ }^{9}$ However, slow charge transfer kinetics at bare $\mathrm{Si}$ and the high recombination rate of electron-hole pairs generated under illumination constitute serious obstacles to promote efficiently multielectron processes. ${ }^{9,10}$ Therefore, the deposition of pure metals $^{9}$, metal oxides or sulfides ${ }^{4,6,11,12}$ onto silicon is an effective way to overcome the intrinsic problems of this semiconductor serving as a photocathode. Among the catalytically active metals, platinum is known as the most efficient electrocatalyst for HER which can 
remain stable either in acidic or alkaline electrolyte..$^{9,13,14,15,16,17,18,19,20,21,22,23}$ It has been demonstrated that Pt, deposited in the form of nanoparticles (NPs), exhibited much higher electrocatalytic activity than that of a continuous $\mathrm{Pt}$ film. ${ }^{9,24}$ Furthermore, the catalytic performances of Pt NPs were found to be highly dependent on their size, their morphology and their shape. ${ }^{25,26,27,28,29,30}$ In that context, attention has been paid to the development of synthetic procedures directed towards the deposition of Pt NPs with high-index facets. ${ }^{31,32,33,34}$ Indeed, the high-index facets are usually more active in chemical reactions and heterogeneous catalytic processes compared with the low-index planes of closely packed surface atoms. As a matter of fact, a surface with high-index planes possesses a high density of terraced, stepped and kinked sites which serve as active sites for a range of reactions. A common route for the synthesis of such shape-controlled Pt NPs involves the gas-phase reduction of a precursor Pt salt in the presence of a capping agent. ${ }^{26,27,35,36,37}$ Electrochemical methods such as potential cycling $^{38}$ and square-wave potential voltammetry ${ }^{31,39,40,41}$ have also been successfully employed for the deposition of Pt NPs with high-index facets onto glassy carbon and graphite surfaces.

In the present work, we exploit another electrochemical approach, namely the electroless deposition by galvanic displacement ${ }^{42,43}$, to grow Pt NPs with different shapes onto photoactive silicon surfaces. In the past, this surfactant-free method has been demonstrated to be a simple and fast procedure to yield Pt NPs-decorated semiconducting surfaces exhibiting improved interfacial charge transfer rates and hydrogen evolution performances. ${ }^{14,17,18,19,22,23}$ We demonstrate herein that both the morphology and the density of Pt nanoparticles deposited on silicon can be finely tuned by electroless deposition temperature and time. In our study, a wide range of temperature $\left(20-75^{\circ} \mathrm{C}\right)$ and time $(1-30 \mathrm{~min})$ has been used to produce a large palette of structurally different Pt nanostructures going from separated spherical nanoparticles to interconnected dendritic structures. In contrast, most of reported electroless metal deposition methods were conducted at ca. room temperature for a few minutes and a single 
type of metal morphology was usually deposited. To the best of our knowledge, this is the first time that the impact of both deposition temperature and time on the electrocatalytic performance of the resulting metallized silicon photocathodes for HER has been addressed with the goal of identifying the most efficient photocathode, in terms of short-circuit current density $\left(J_{\mathrm{sc}}\right)$, fill factor $(F F)$ and thermodynamic efficiency for production of $\mathrm{H}_{2}(\eta){ }^{5}$

\section{Experimental}

2.1. Reagents. Acetone (MOS electronic grade, Erbatron from Carlo Erba) and anhydrous ethanol (RSE electronic grade, Erbatron from Carlo Erba) were used without further purification. The chemicals used for the cleaning and etching of silicon wafer pieces $(30 \%$ $\mathrm{H}_{2} \mathrm{O}_{2}, 96-97 \% \mathrm{H}_{2} \mathrm{SO}_{4}$ and $50 \%$ HF solutions) were of VLSI $\left(\mathrm{H}_{2} \mathrm{O}_{2}\right.$, from Sigma-Aldrich) and $\operatorname{MOS}\left(\mathrm{H}_{2} \mathrm{SO}_{4}\right.$ from O-BASF and HF from Sigma-Aldrich) semiconductor grade.

2.2. Preparation of Pt-decorated silicon surfaces. A piece of $p$-type $\operatorname{Si}(100)(1-5 \Omega \mathrm{cm}$ resistivity, boron doped, $250 \mu \mathrm{m}$ thickness, Siltronix) was sonicated for 10 minutes successively in acetone, ethanol and ultra-pure $18.2 \mathrm{M} \Omega \mathrm{cm}$ water (Veolia Water STI) to degrease it. It was then cleaned with piranha solution $\left(3: 1 \mathrm{v} / \mathrm{v}\right.$ concentrated $\left.\mathrm{H}_{2} \mathrm{SO}_{4} / 30 \% \mathrm{H}_{2} \mathrm{O}_{2}\right)$ for $30 \mathrm{~min}$ at $100^{\circ} \mathrm{C}$, followed by copious rinsing with ultra-pure water to eliminate heavy metals and organic residues.

Caution: The concentrated aqueous $\mathrm{H}_{2} \mathrm{SO}_{4} / \mathrm{H}_{2} \mathrm{O}_{2}$ (piranha) solution is very dangerous, particularly in contact with organic materials, and should be handled extremely carefully.

Hydrogen-terminated $\mathrm{Si}(100)$ (H-Si) was obtained by immersing the $\mathrm{Si}(100)$ substrate previously decontaminated with piranha solution into $\mathrm{HF} 10 \%$ wt $(\sim 5.7 \mathrm{M})$ for $2 \mathrm{~min}$, followed by drying under an argon stream.

Caution: Proper precautions must be used when handling hydrogen fluoride. Hydrogen fluoride is extremely corrosive to human tissue, contact resulting in painful, slow-healing 
burns. Laboratory work with HF should be conducted only in an efficient hood, with the operator wearing a full-face shield and protective clothing.

Pt-coated silicon surfaces were obtained by electroless deposition in the presence of HF. A freshly prepared $\mathrm{H}-\mathrm{Si}$ sample was dipped for a time varying between 1 and 30 min into a solution of $\mathrm{Na}_{2} \mathrm{PtCl}_{4}$ (Strem Chemicals) at $1 \mathrm{mM}$ in $\mathrm{HF} 10 \%$. The metallic salt solution was previously kept at $\mathrm{rt}$ or heated at $45^{\circ} \mathrm{C}, 60^{\circ} \mathrm{C}$ or $75^{\circ} \mathrm{C}$ for $30 \mathrm{~min}$ before the introduction of $\mathrm{H}$ $\mathrm{Si}$ and kept at the selected temperature throughout the course of the reaction. The metallized surface was thoroughly rinsed with ultrapure water and dried under an argon stream. It was then immediately used for (photo)electrochemical measurements.

2.3. Electrochemical Characterization. All the electrochemical experiments were performed in a home-made three-electrode glass cell comprising a quartz window. The electrical contact with the working electrode was made by applying a drop of In-Ga eutectic (Alfa Aesar, 99.99\%) on the previously polished backside of the silicon electrode. $\mathrm{KCl}$ saturated calomel electrode (SCE) was used as the reference electrode. A glassy carbon rod was used as the counter electrode. Potentials vs SCE were converted into potentials vs reversible hydrogen electrode (RHE) from measurements of the open-circuit potential (OCP) of a clean Pt electrode in the $\mathrm{pH} 1$ solution saturated with research grade $\mathrm{H}_{2}$ (Air-Liquide, 99.999\%). The OCP potential was measured to be $-0.300 \pm 0.005 \mathrm{~V}$ vs SCE, in close agreement with the theoretically predicted value by the expression: $\mathrm{V}_{\mathrm{RHE}}=\mathrm{V}_{\mathrm{SCE}}+0.24+$ $0.059 * \mathrm{pH}$. All the linear sweep voltammograms were $i R$-corrected using the resistance determined by impedance spectroscopy at high frequency $(100 \mathrm{kHz})$. Typical values of $26 \pm 5$ ohm were obtained for our different photoelectrochemical cells and were found to be not really dependent on the type of metallized photoelectrode.

Electrochemical Measurements. Linear sweep voltammetry (LSV) and chronoamperometry were performed with an Autolab electrochemical analyzer (PGSTAT 30 potentiostat/galvanostat from Eco Chemie B.V.) equipped with the GPES and FRA software. 
The aqueous solution containing sodium sulfate $\left(\mathrm{Na}_{2} \mathrm{SO}_{4}\right.$, Carlo Erba, $\left.99.6 \%\right)$ at $0.5 \mathrm{M}$ was adjusted to $\mathrm{pH} 1$ with $\mathrm{H}_{2} \mathrm{SO}_{4}$ and was continuously stirred with a stir bar during the electrochemical measurements. We have checked that the addition of $\mathrm{Na}_{2} \mathrm{SO}_{4}$ into the acidic solution did affect neither the potential scale nor the photoelectrochemical measurements at metallized H-Si photocathodes. The geometrical area of silicon exposed to light was $0.2 \mathrm{~cm}^{2}$. All the electrochemical measurements were carried out inside a home-made Faraday cage at room temperature and under a constant flux of argon.

2.4. Additional Instrumentation. Light source. The light source used for the photoelectrochemical experiments with silicon electrodes was an optical fiber (Fiber Light DC950H from Dolan Jenner), equipped with a $150 \mathrm{~W}$ quartz halogen. The fluence of the lamp at the position occupied by the silicon working electrode was measured as $33 \mathrm{~mW} \mathrm{~cm} \mathrm{~cm}^{-2}$ by using an optical power/energy meter (Model 842-PE, Newport) coupled to a silicon photodiode (Model 918D-SL-OD3, Newport). This value corresponds to the maximum power

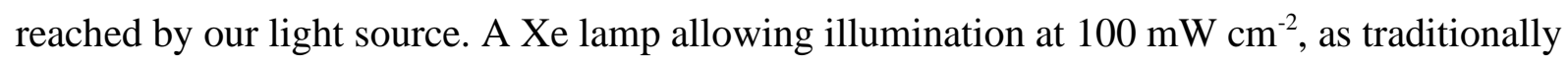
used in this kind of photoelectrocatalytic experiments, was not currently available in our lab.

Scanning Electron Microscopy. A JEOL JSM-7100F Scanning Electron Microscope (SEM) was used to analyze the morphology of Pt-coated silicon surfaces as a function of both the metal deposition temperature and time. The images were processed by the ImageJ (version 1.45s) software to determine the number density of Pt particles deposited on $\mathrm{H}-\mathrm{Si}(100)$ surfaces. The procedure to count the Pt particles was as follows. First, the "Analyze/Set Scale" dialog box was used to define the spatial scale from the scale bar in the SEM images. The "Analyze particles" automated routine was then used to count and outline the Pt particles. The data window was copied and pasted to a OriginPro 8.5 spreadsheet.

\section{Results and Discussion.}


3.1. Morphology of the Pt NPs deposited on H-Si. Figure 1 shows the SEM images of Pt NPs deposited on H-Si by electroless galvanic displacement at different temperatures for 5 min from an aqueous HF-containing metallic solution at $1 \mathrm{mM}$. The Pt NPs were of hexoctahedron shape ${ }^{44}$ when the deposition temperature was fixed between 22 and $60^{\circ} \mathrm{C}$. For a temperature of $75^{\circ} \mathrm{C}$, a mixture of hexaoctahedra and highly branched structures was observed. Furthermore, the density of deposited Pt NPs decreased upon increasing the deposition temperature from 22 to $75^{\circ} \mathrm{C}$. The number density calculated by SEM (Figure S1, Supporting Information) was around $(4.5 \pm 1.0) \times 10^{8},(3.5 \pm 0.8) \times 10^{8},(3.0 \pm 0.6) \times 10^{8}$ and $(2.0 \pm 0.5) \times 10^{8} \mathrm{Pt}$ NPs per $\mathrm{cm}^{2}$ of the silicon surface at $22,45,60$ and $75^{\circ} \mathrm{C}$, respectively. Moreover, the average size of the observed features monotonously increased from 120 to 250 $\mathrm{nm}$ within this temperature range with an approximately constant size distribution until $60^{\circ} \mathrm{C}$ enlarging at $75^{\circ} \mathrm{C}$ (the width at half-maximum was found to be $35 \pm 5 \mathrm{~nm}$ within the $22-60^{\circ} \mathrm{C}$ range and increased to $120 \pm 10 \mathrm{~nm}$ at $75^{\circ} \mathrm{C}$ ). It is worth mentioning that the average surface occupied by the Pt particles was determined to be around $9 \pm 1 \%$ of the total silicon surface and was found to be not significantly dependent on the deposition temperature. For all investigated temperatures, the metal deposition mechanism involved the attack of the bulk silicon concomitantly with the growth of isolated Pt NPs which resulted ultimately in the formation of nanotrenches surrounding the Pt NPs (Figures 1 and S2). The morphology of the grown Pt NPs was not only dependent on the deposition temperature but also on the immersion time. The latter parameter has been examined more in detail for two representative temperatures: 45 and $75^{\circ} \mathrm{C}$. For $45^{\circ} \mathrm{C}$, Pt NPs were essentially of hexoctahedron shape when the deposition time did not exceed $10 \mathrm{~min}$. For times longer than $15 \mathrm{~min}$, highly branched structures, grown from the corners of the polyhedral, were observed leading to the formation of a few hundred $\mathrm{nm}$ long $\mathrm{Pt}$ dendrites after $30 \mathrm{~min}$ deposition (Figure 2). When the temperature was fixed at $75^{\circ} \mathrm{C}$, the transition between hexoctahedron and highly branched 
structures occurred at shorter times, between 1 and $5 \mathrm{~min}$. Long dendrites standing out of silicon trenches were clearly visible from 10 min (Figure 3).

To sum-up, isolated Pt structures can be produced at all investigated temperatures for short deposition times, typically within $1-10 \mathrm{~min}$ if the temperature was $45^{\circ} \mathrm{C}$ or less than $5 \mathrm{~min}$ at $75^{\circ} \mathrm{C}$. For longer times, dendritic metal structures start to grow leading ultimately to highly rough interconnected Pt networks. As detailed in the next section, such differences in both the morphology and the density of deposited Pt NPs have a strong impact on the electrocatalytic performances for HER of metallized surfaces. 
$22^{\circ} \mathrm{C}$
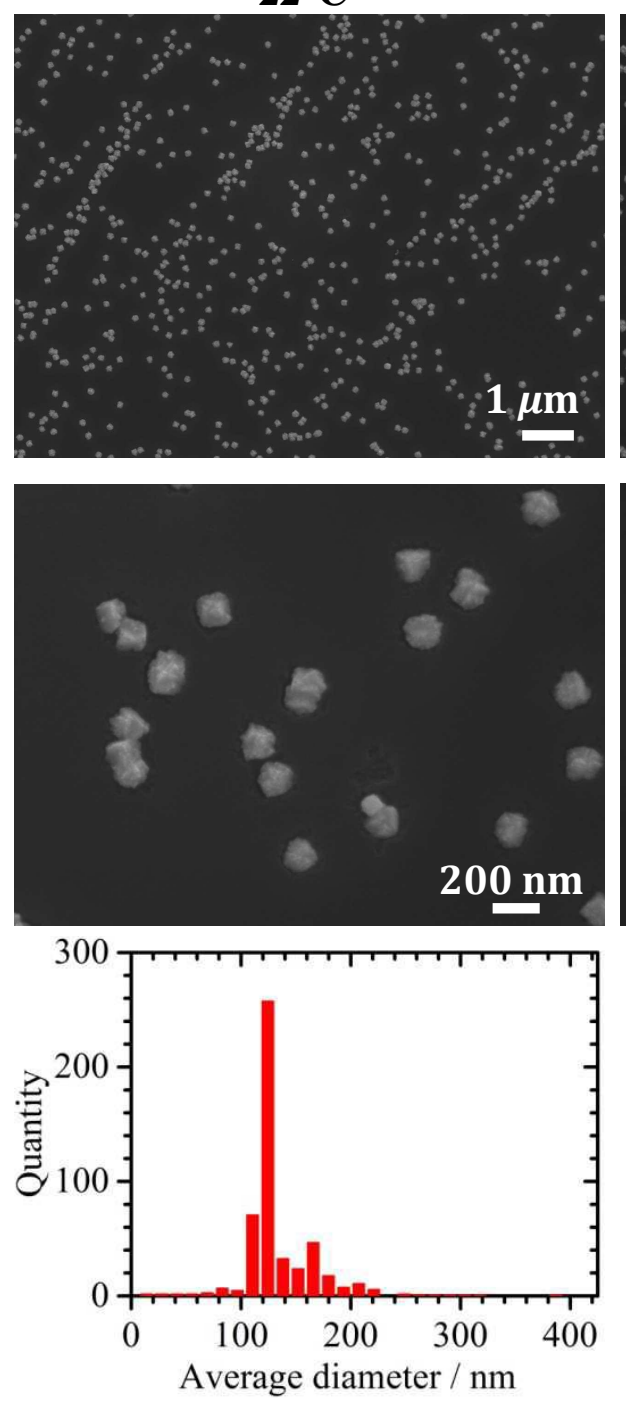

$45^{\circ} \mathrm{C}$
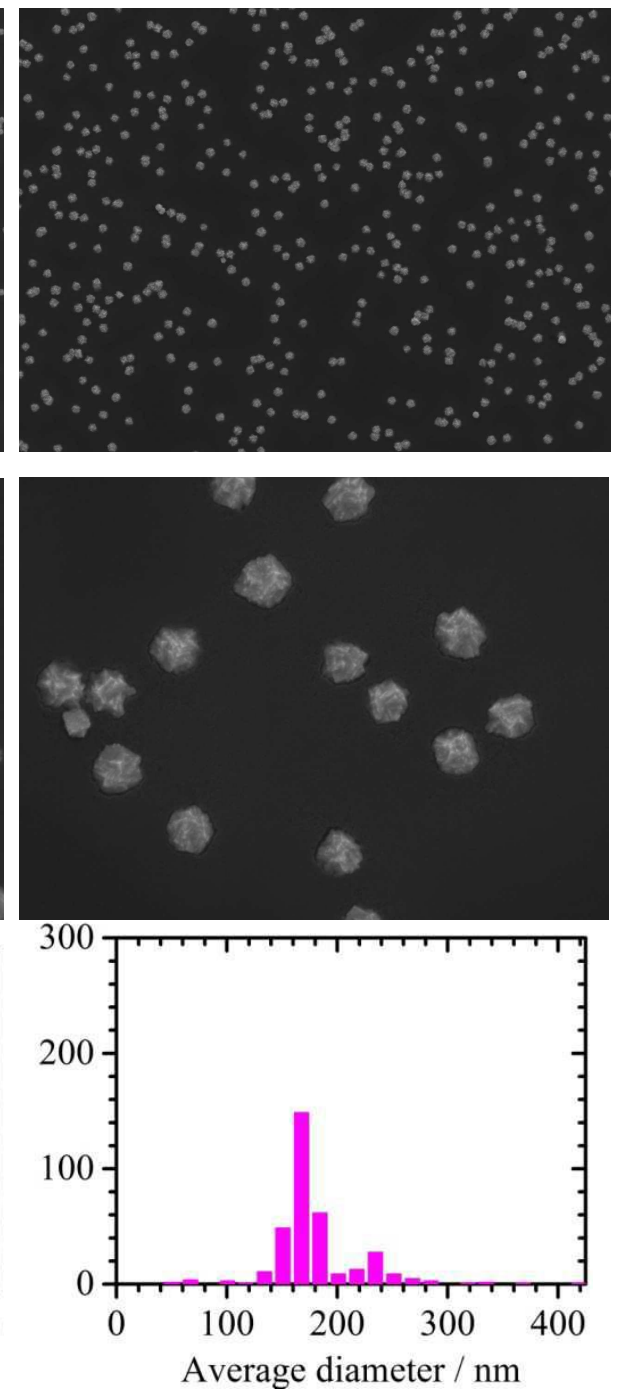

$60^{\circ} \mathrm{C}$
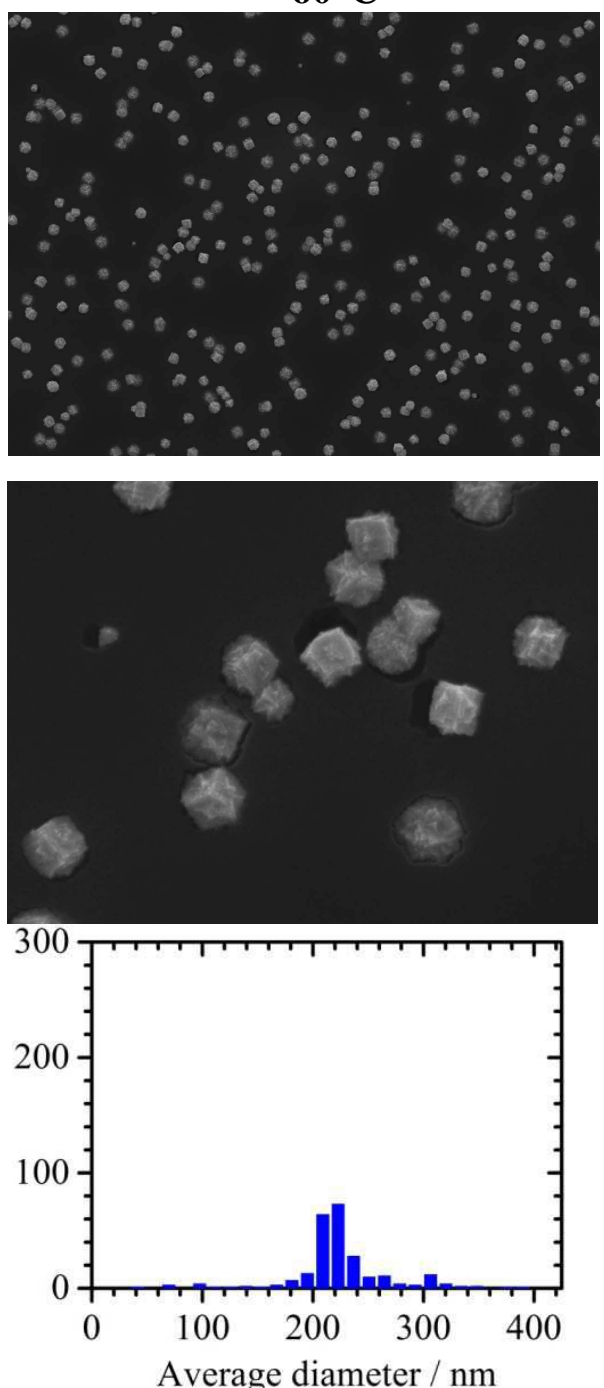

$75^{\circ} \mathrm{C}$
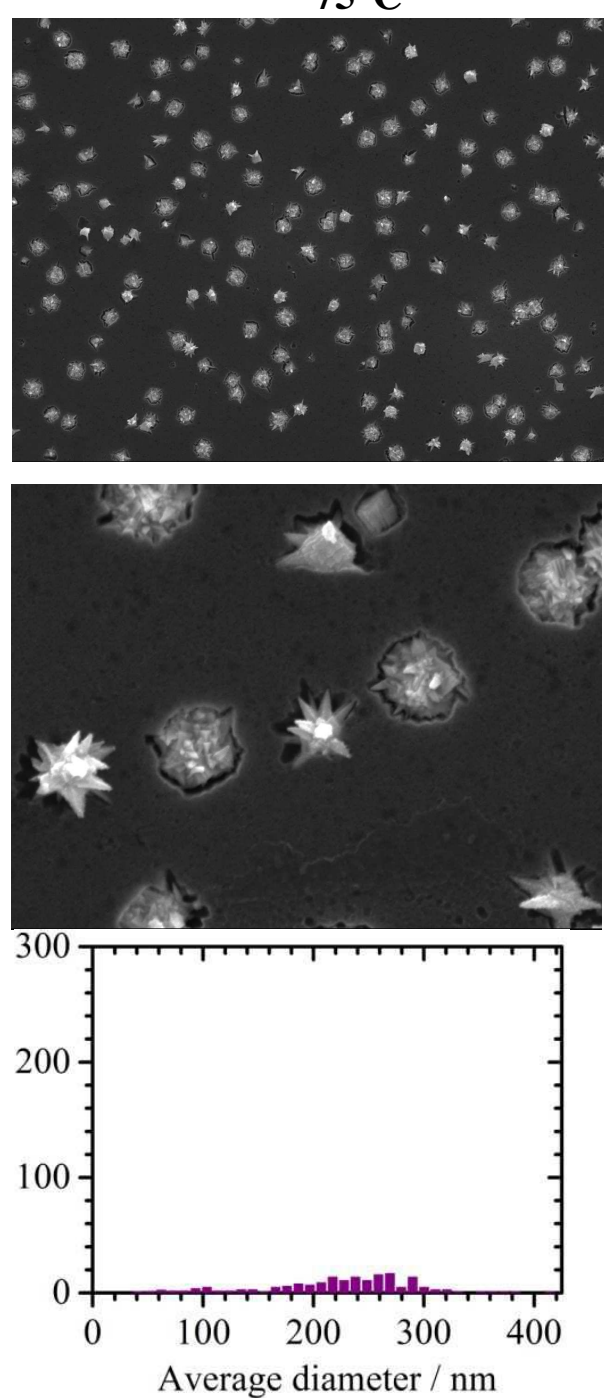
Figure 1. (Top, middle) SEM Images of flat H-Si(100) surfaces after electroless deposition of Pt at different temperatures for 5 min. Deposition solution: $\mathrm{Na}_{2} \mathrm{PtCl}_{4}$ at $1 \mathrm{mM}$ in $\mathrm{HF}$ 5.7 M. (Bottom) Corresponding particle size distributions.

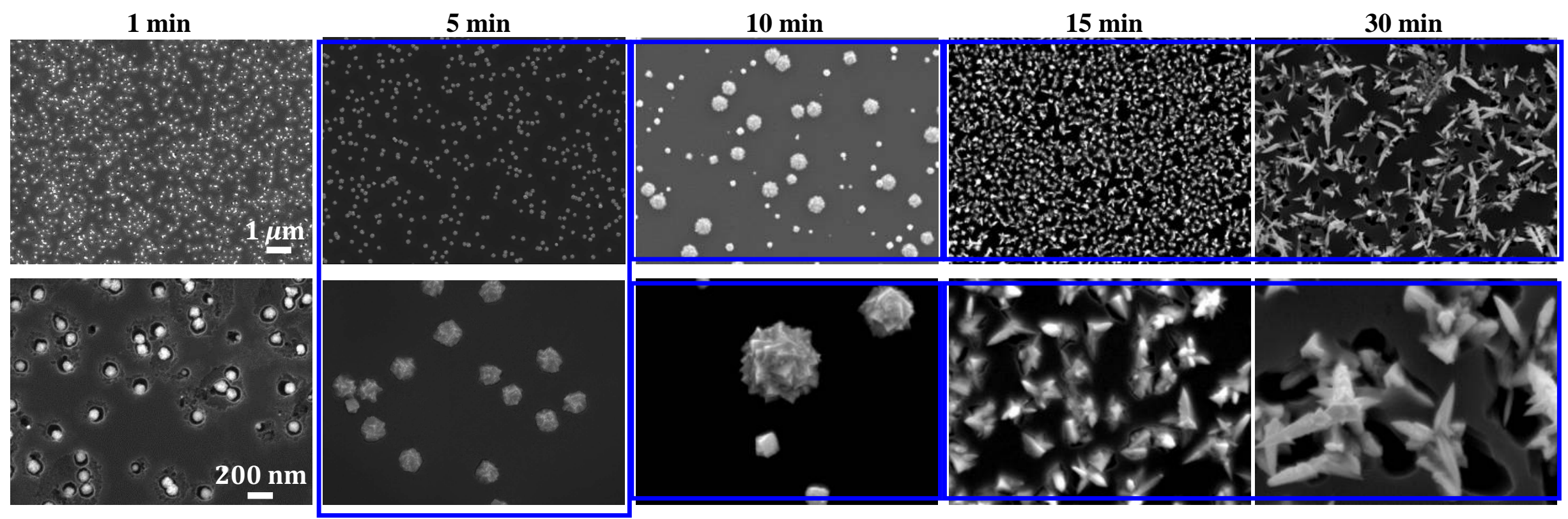

Figure 2. SEM Images of flat $\mathrm{H}-\mathrm{Si}(100)$ surfaces after electroless deposition of $\mathrm{Pt}$ at $45^{\circ} \mathrm{C}$ for $1,5,10,15$ and 30 min. Deposition solution: $\mathrm{Na}_{2} \mathrm{PtCl}_{4}$ at $1 \mathrm{mM}$ in $\mathrm{HF} 5.7 \mathrm{M}$. 


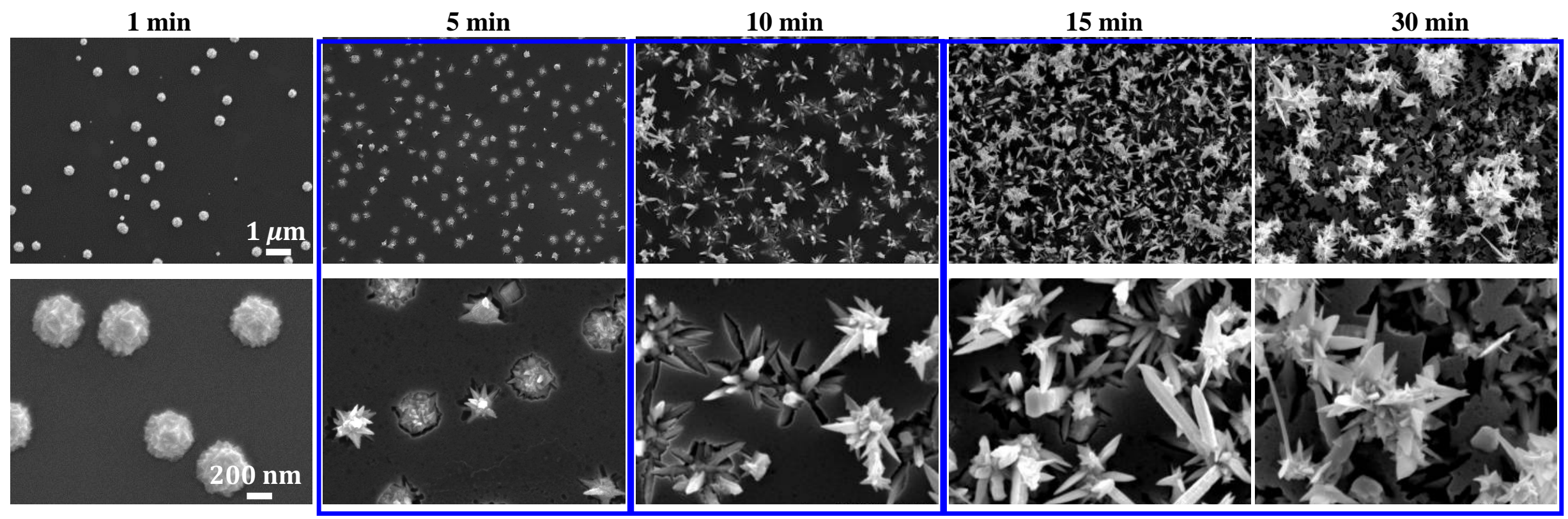

Figure 3. SEM Images of flat $\mathrm{H}-\mathrm{Si}(100)$ surfaces after electroless deposition of Pt at $75^{\circ} \mathrm{C}$ for $1,5,10,15$ and 30 min. Deposition solution: $\mathrm{Na}_{2} \mathrm{PtCl}_{4}$ at $1 \mathrm{mM}$ in $\mathrm{HF} 5.7 \mathrm{M}$. 
3.2. Electrocatalytic HER at platinized H-Si photocathodes. Figure 4 shows the $i R$-corrected polarization curves obtained at $\mathrm{Si}$ photocathodes which had been previously metallized at different temperatures for $5 \mathrm{~min}$. As expected, no appreciable reduction current was measured in the dark for all the electrodes. Under illumination with a halogen lamp $(33 \mathrm{~mW} \mathrm{~cm})^{-2}$, they exhibited much higher electrocatalytic performance than that of nonmetallized H-Si(100). For example, the overpotential for hydrogen evolution was significantly decreased by ca. $940 \mathrm{mV}$ with respect to $\mathrm{H}-\mathrm{Si}(100)$ (measured for a current density of $5.0 \mathrm{~mA} \mathrm{~cm}{ }^{-2}$ ) under identical illumination conditions. We now examine in more details the effects of the metal deposition temperature on the electrocatalytic behavior of the photoelectrodes. Qualitatively, the cathodic photocurrent densities corresponding to HER were significantly higher at photocathodes metallized at temperatures above $45^{\circ} \mathrm{C}$. In contrast, the open-circuit voltage $V_{\text {oc }}$ (the difference between the potential at which the photoelectrode passed no current and the formal potential of the $\mathrm{H}^{+} / \mathrm{H}_{2}$ redox couple $)^{5}$ was constant at $450 \pm 10 \mathrm{mV}$ vs RHE and not dependent on the deposition temperature. For all the metallized photoelectrodes, it is worth noting that the catalytic photocurrent decreased slightly for potentials below $0.0 \mathrm{~V}$ vs RHE instead of being flat as expected for light-limited catalytic current. Such a trend is thought to be due to the gradual decrease in the active surface area of the photoelectrode caused by the accumulation of $\mathrm{H}_{2}$ bubbles which were not totally removed from the surface upon stirring.

To evaluate quantitatively the respective catalytic performance of each metallized electrode, two other characteristic parameters have been determined, namely the fill factor $(F F$, eq 1$)$ and the thermodynamic efficiency for $\mathrm{H}_{2}$ evolution $(\eta$, eq 2$) .^{5}$

$$
F F=\frac{P_{\max }}{V_{\mathrm{oc}} \cdot\left|J_{\mathrm{sc}}\right|}
$$




$$
\eta=\frac{P_{\max }}{P_{\text {in }}}=\frac{F F \cdot V_{\mathrm{oc}} \cdot\left|J_{\mathrm{sc}}\right|}{P_{\mathrm{in}}}
$$

where $P_{\max }$ is the maximum product of $|J|$ and $E,\left|J_{\mathrm{sc}}\right|$ is the short-circuit current density (at $E=$ $0 \mathrm{~V} v s \mathrm{RHE}$ ) and $P_{\text {in }}$ is the incoming light intensity (i.e. $33 \mathrm{~mW} \mathrm{~cm}{ }^{-2}$ ). The results are gathered in Figure 5. The values of $F F(25 \%), \eta(<0.01 \%)$ and $\left|J_{\mathrm{sc}}\right|\left(0.02 \mathrm{~mA} \mathrm{~cm} \mathrm{~cm}^{-2}\right.$ at $0 \mathrm{~V}$ vs RHE) calculated for $\mathrm{H}-\mathrm{Si}$ are consistent with the poor activity of this photoelectrode for HER. In contrast, the photoelectrodes metallized at temperatures between 45 and $75^{\circ} \mathrm{C}$ were the most active with comparable $F F(40-45 \%), \eta(9-10 \%)$ and $\left|J_{\mathrm{sc}}\right|\left(14.5-15.5 \mathrm{~mA} \mathrm{~cm}{ }^{-2}\right)$. The surface metallized at $22^{\circ} \mathrm{C}$ exhibited a lower HER activity, as supported by smaller $\eta(6.7 \%)$ and $\left|J_{\text {sc }}\right|$ $\left(12 \mathrm{~mA} \mathrm{~cm}^{-2}\right)$.

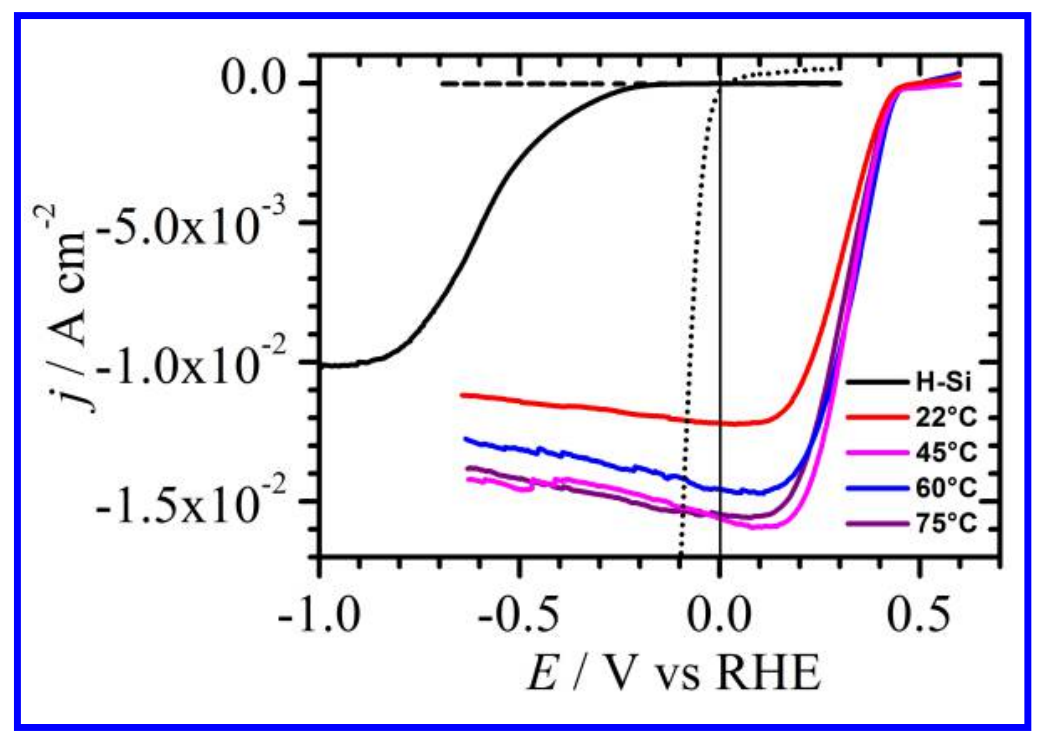

Figure 4. Linear sweep voltammograms at $20 \mathrm{mV} \mathrm{s}^{-1}$ of Pt-coated $\mathrm{Si}(100)$ electrodes in $\mathrm{H}_{2} \mathrm{SO}_{4}$ solution containing $0.5 \mathrm{M} \mathrm{Na}_{2} \mathrm{SO}_{4}(\mathrm{pH}$ 1), in the dark (dashed trace) and under illumination (solid traces). Pt was electroless deposited at different temperatures for 5 min from a HF $5.7 \mathrm{M}$ solution containing $\mathrm{Na}_{2} \mathrm{PtCl}_{4}$ at $1 \mathrm{mM}$. The black solid and dotted traces correspond to the response of bare H-Si under illumination and Pt disk electrode, respectively. 


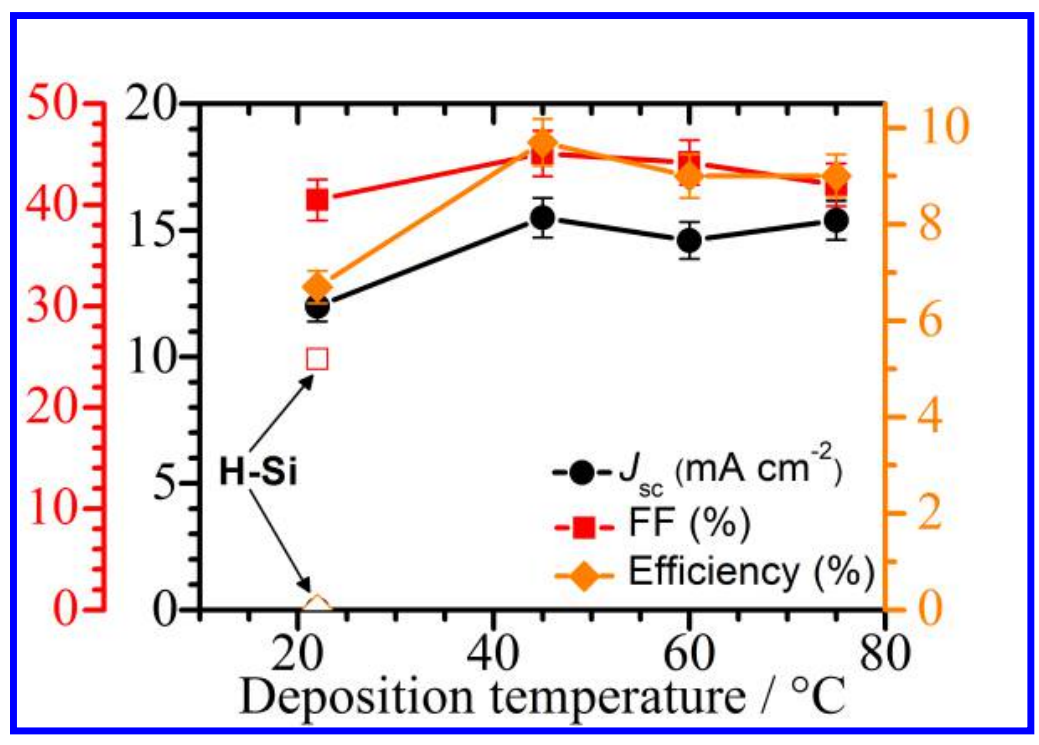

Figure 5. Figures of merit of photocathodes metallized at different temperatures for $5 \mathrm{~min}$.

The polarization curves of the silicon photoelectrodes metallized at two representative temperatures, namely 45 and $75^{\circ} \mathrm{C}$, for different times are shown in Figures 6 and 7 . For $45^{\circ} \mathrm{C}$, $V_{\text {oc }}$ was found to increase from 320 to $450 \mathrm{mV}$ vs RHE upon increasing deposition time from 1 to $5 \mathrm{~min}$, then remained approximately constant at $(450 \pm 20) \mathrm{mV}$ for longer times. The $F F, \eta$ and $\left|J_{\text {sc }}\right|$ values calculated as a function of the deposition time (Figure 8) demonstrated that the photoelectrode metallized for 5 min exhibited the best catalytic activity $(F F=45 \%, \eta=9.7 \%$ and $\left|J_{\mathrm{sc}}\right|=15.5 \mathrm{~mA} \mathrm{~cm} \mathrm{~cm}^{-2}$. Times smaller than $3 \mathrm{~min}$ were found to yield less active photoelectrodes with smaller $F F(18-30 \%), \eta(2.2-5.0 \%)$ and $\left|J_{\mathrm{sc}}\right|\left(12.5-14.4 \mathrm{~mA} \mathrm{~cm}^{-2}\right)$ values. The photoelectrodes metallized for times longer than 15 min exhibited catalytic performances which were only slightly lower than those obtained for the photoelectrode metallized for 5 min. Such a situation can be partially explained by the concomitant formation of nanotrenches in the silicon bulk and the growth of branched Pt structures (Figure 2). As previously suggested, enlarging the semiconductor/metal junction area deep toward the bulk would lead to improved efficiencies. $^{9}$ 
Figure 6. Linear sweep voliammograms al $20 \mathrm{mV}_{\mathrm{S}}$ of Pt-coated ST(100) electrodes in $\mathrm{H}_{2} \mathrm{SO}_{4}$ solution containing $0.5 \mathrm{M} \mathrm{Na}_{2} \mathrm{SO}_{4}(\mathrm{pH}$ 1) under illumination. Pt was electroless deposited at $45^{\circ} \mathrm{C}$ for different times from a $\mathrm{HF}$ 5.7 M solution containing $\mathrm{Na}_{2} \mathrm{PtCl}_{4}$ at $1 \mathrm{mM}$.

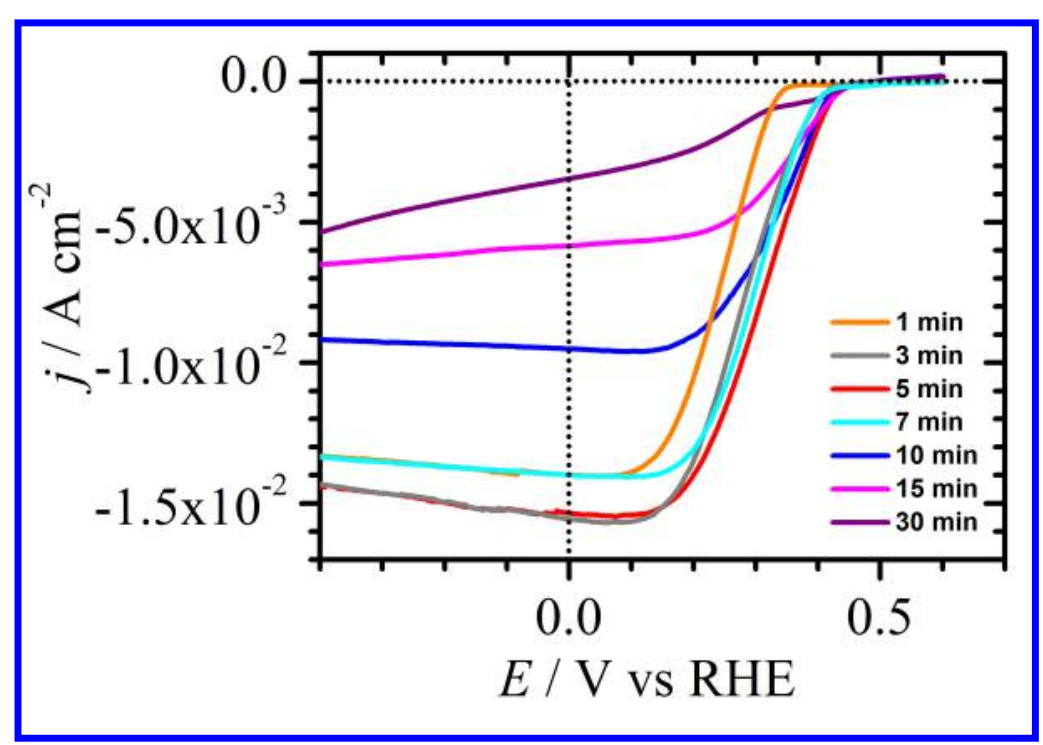

Figure 7. Linear sweep voltammograms at $20 \mathrm{mV} \mathrm{s}^{-1}$ of Pt-coated $\mathrm{Si}(100)$ electrodes in $\mathrm{H}_{2} \mathrm{SO}_{4}$ solution containing $0.5 \mathrm{M} \mathrm{Na}_{2} \mathrm{SO}_{4}(\mathrm{pH}$ 1) under illumination. Pt was electroless deposited at $75^{\circ} \mathrm{C}$ for different times from a $\mathrm{HF} 5.7 \mathrm{M}$ solution containing $\mathrm{Na}_{2} \mathrm{PtCl}_{4}$ at $1 \mathrm{mM}$. 
As seen in the SEM pictures, the formation of nanotrenches was observed at shorter deposition times (less than $5 \mathrm{~min}$ ) when the surface was metallized at $75^{\circ} \mathrm{C}$. As a result, the catalytic performances of the surfaces metallized at this temperature for 1 and 3 min were higher than those metallized at $45^{\circ} \mathrm{C}$ for the same times (Figure 8). $V_{\mathrm{oc}}$ was raised from 355 to $450 \mathrm{mV}$ by increasing the time from 1 to $3 \mathrm{~min}$, then remained constant at approximately $(450 \pm 20) \mathrm{mV}$ for longer times. The best compromise between catalytic efficiency and photocurrent was obtained for an optimal deposition time of $5 \min \left(F F=42 \%, \eta=9.0 \%\right.$ and $\left.\left|J_{\mathrm{sc}}\right|=15.4 \mathrm{~mA} \mathrm{~cm}{ }^{-2}\right)$. The catalytic activity of such a photoelectrode was quite similar to that of the best photoelectrode produced at $45^{\circ} \mathrm{C}$ for $5 \mathrm{~min}$. However, in contrast with the surfaces metallized at $45^{\circ} \mathrm{C}, J_{\mathrm{sc}}$ and $\eta$ were found to decrease dramatically for times exceeding $10 \mathrm{~min}$. Three possible reasons can be involved to explain such a trend. First, it is very likely that the density of surface defects increases with the deposition time and these sites act as recombination centers of the photogenerated charge carriers lowering the overall catalytic efficiency. ${ }^{9}$ The second one is related to the high coverage of the Pt layer from 15 min (as supported by SEM, Figure 3) which would limit the amount of light absorbed by silicon and thus would reduce the photocurrent. ${ }^{5,15}$ The third one concerns the less efficient injection of photogenerated charge carriers with the progressive conversion of the metal layer from well-dispersed and isolated islands at short times to an interconnected metal structure for times longer than $15 \mathrm{~min}$.

The UV-visible reflectance measurements performed with surfaces metallized at 45 and $75^{\circ} \mathrm{C}$ indicate that the light-harvesting properties of these surfaces were globally improved upon increasing the deposition time (Figure S3, Supporting Information). Consequently, the decrease of the catalytic properties of the photoelectrodes obtained at long deposition times would 
probably result from accelerated charge recombination and less efficient charge injection phenomena.
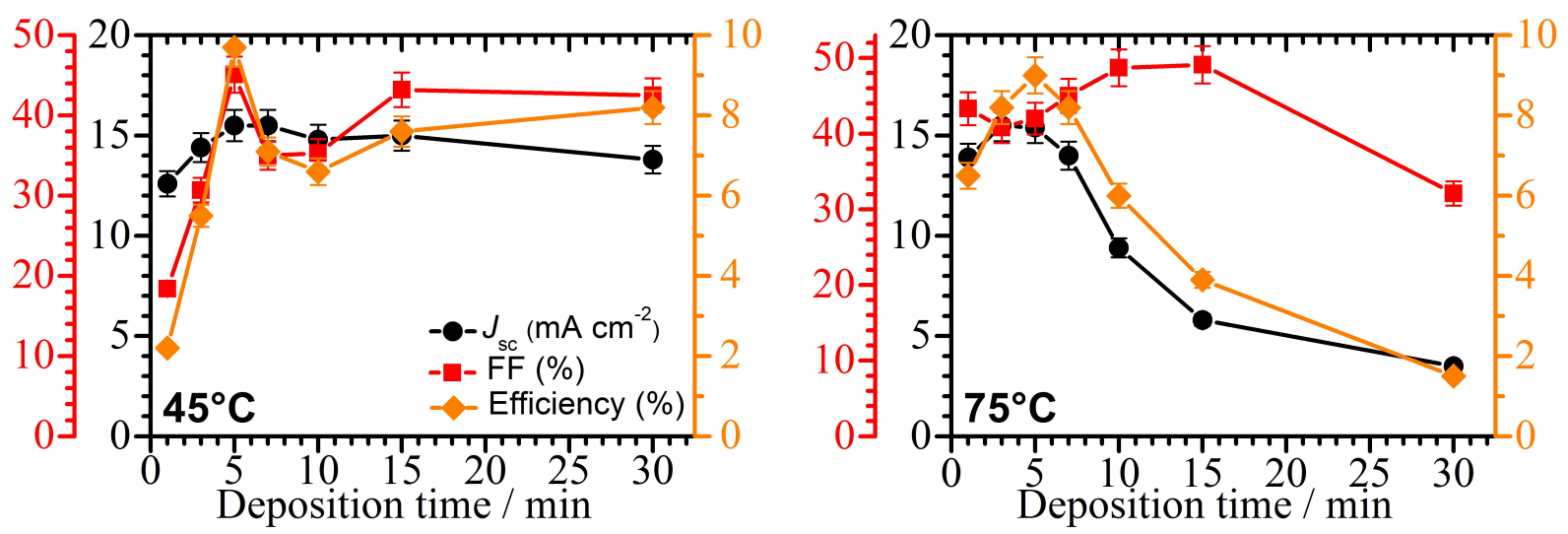

Figure 8. Catalytic performances of the Pt-coated photoelectrodes as a function of the $\mathrm{Pt}$ deposition temperature (deposition time: $5 \mathrm{~min}$ ). The continuous lines are a guide for the eyes.

3.3. Stability of the optimized photoelectrode for HER. The photoelectrode exhibiting the best electrocatalytic efficiency (namely, that prepared at $45^{\circ} \mathrm{C}$ for $5 \mathrm{~min}$ ) was tested over one hour at $0.0 \mathrm{~V}$ vs RHE under illumination $\left(33 \mathrm{~mW} \mathrm{~cm}^{-2}\right)$. As shown in Figure 9, the photocurrent produced with this photoelectrode remained relatively stable during the electrolysis time. The amount of $\mathrm{H}_{2}$ produced was determined from the gas volume by measuring the amount of the electrolytic solution displaced in a sealed and graduated upside-down burette (Hoffman cell). ${ }^{45}$ $\mathrm{H}_{2}$ was evolved with a constant rate of $110 \pm 20 \mu \mathrm{mol} \mathrm{h}^{-1}$ and a Faradaic yield $>90 \%$. $\mathrm{O}_{2}$ evolution at the Pt counter electrode was also monitored and the overall molar ratio of the evolved $\mathrm{H}_{2}: \mathrm{O}_{2}$ was $2.5 \pm 0.2$ (Figure 9b). These deviations from the expected Faradaic yield of $100 \%$ and stoichiometric ratio of 2:1 are believed to be due to the uncertainty in the gas volume measurements with the Hoffman cell and to a possible reduction of a small fraction of the $\mathrm{O}_{2}$ 
generated at the anode. However, these results clearly show that such photocathode is robust enough to be operated for $\mathrm{H}_{2}$ production during a reasonable amount of time.

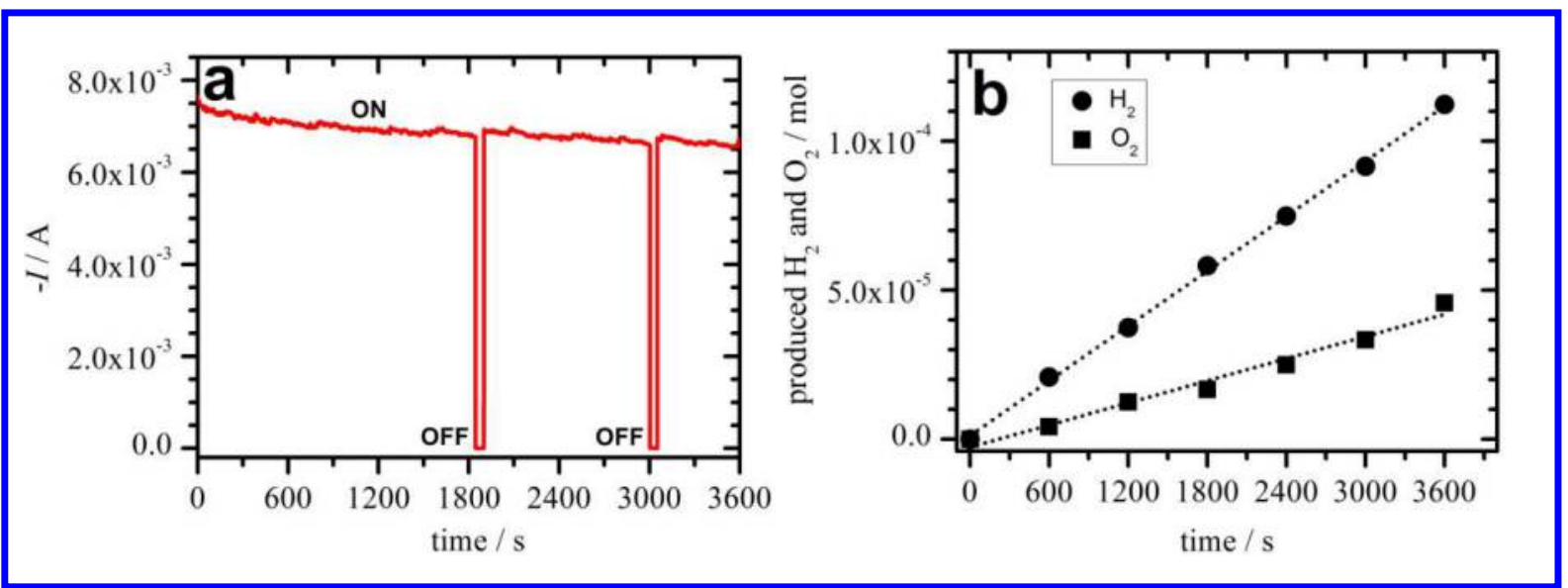

Figure 9. (a) Current-time curve obtained by controlled-potential electrolysis at $0.0 \mathrm{~V}$ vs RHE for the photoelectrode prepared at $45^{\circ} \mathrm{C}$ for $5 \mathrm{~min}$ in $\mathrm{H}_{2} \mathrm{SO}_{4}$ solution containing $0.5 \mathrm{M} \mathrm{Na}_{2} \mathrm{SO}_{4}$ (pH 1) under illumination at $33 \mathrm{~mW} \mathrm{~cm}^{-2}$ (ON state) with two dark periods (OFF state). (b) Amount of $\mathrm{H}_{2}$ and $\mathrm{O}_{2}$ evolved at the photoelectrode and the Pt counter electrode, respectively, as a function of the electrolysis time. The number of mole of produced gas was calculated from gas volume in a Hoffman cell.

\subsection{Comparison with other Pt NPs-decorated H-Si photocathodes. Table 1 lists the reported} HER performances of several Pt-metallized Si photocathodes using different deposition methods (electroless, electrochemical, evaporation and atomic layer deposition ALD). Two types of electrode structures have been considered, namely planar and micro-/nanostructured silicon. Globally, the optimized photoelectrode prepared in this study exhibits the best catalytic activity, in terms of $V_{\text {oc }}, F F$ and $\eta$, compared with other photoelectrodes based on planar silicon. The smaller value of $J_{\mathrm{sc}}$ found herein can be reasonably ascribed to the lower illumination power. 
From Table 1, it is also evident that the electrochemical deposition methods failed to produce photocathodes with high $V_{\mathrm{oc}}$ and $\eta$. Moreover, it is worth mentioning that the exceptional efficiency reported by Lombardi et al. $(>10 \%)^{15}$ has been calculated for a three-electrode electrochemical cell using the expression available for a complete water splitting photoelectrode device $^{5}$ and consequently is an overestimate of the real efficiency of the individual HER photocathode. Compared with structured photoelectrodes, our optimized planar photocathode exhibits a comparable or higher catalytic performance. The use of Si micro- and nanowires as electrode materials was found to significantly improve $V_{\mathrm{oc}}$ relative to the planar electrodes. Nevertheless, the measured photocurrent densities were not significantly enhanced as expected for such high surface area structures. This well-known trend has been attributed to a less efficient light absorption by the wires essentially due to the high density of surface states. ${ }^{9}$ Furthermore, the use of a high-cost metal deposition technique, such as atomic layer deposition (ALD), yielded photocathodes with small $J_{\mathrm{sc}}$ and $\eta$, in spite of a uniform distribution of Pt NPs along the wires. ${ }^{20}$ As a matter of fact, the only configuration allowing outstanding HER performance included $\mathrm{a}^{+} \mathrm{p}$ radial junction in planar or Si wire-array structures. ${ }^{18} F F$ higher than $50 \%$ with $V_{\text {oc }}$ of ca. $0.55 \mathrm{~V}$ vs RHE were measured for such photoelectrodes. 
Table 1. Key HER catalytic parameters for different Pt metallized silicon photocathodes.

\begin{tabular}{|c|c|c|c|c|c|c|c|c|}
\hline $\begin{array}{l}\text { Pt } \\
\text { deposition } \\
\text { method }^{a}\end{array}$ & $\begin{array}{l}\text { Pt deposition } \\
\text { conditions }\end{array}$ & $\begin{array}{l}\text { Illumination } \\
\text { power } \\
/ \mathrm{mW} \mathrm{cm}^{-2}\end{array}$ & $\mathrm{pH}$ & $\begin{array}{l}V_{\text {oc }} / \mathrm{V} v s \\
\mathrm{RHE}\end{array}$ & $\begin{array}{l}-J_{\mathrm{sc}} / \mathrm{mA} \\
\mathrm{cm}^{-2}\end{array}$ & $\begin{array}{l}F F \\
/ \%\end{array}$ & $\begin{array}{l}\eta \\
1 \%\end{array}$ & Ref. \\
\hline \multicolumn{9}{|c|}{ Planar p-Si } \\
\hline EL & $5 \min @ 45^{\circ} \mathrm{C}$ & 33 & 1 & 0.46 & 15.5 & 45 & 9.7 & This work \\
\hline EL & 3-8 min@rt & 100 & 4.5 & $0.21-0.25$ & $10-22$ & $12-22$ & $0.3-1.1$ & 17 \\
\hline Echem & $-2 \mathrm{~V}^{b}$ for $4.5 \mathrm{~s}$ & 100 & 4.5 & 0.27 & 21.5 & 33 & 1.9 & 16 \\
\hline EL & 2-10 min@rt & $10-100$ & 1 & $\sim 0.30$ & $2-20^{c}$ & $-{ }^{d}$ & $25-10^{c, e}$ & 15 \\
\hline EL & 〜10 min@rt & 100 & 2 & 0.30 & 23 & 30 & 2.1 & 18 \\
\hline Echem & $-0.3 \mathrm{~V}^{f}$ & $6.4-11.8^{g}$ & 1.3 & 0.26 & $0.8^{h}$ & $-d$ & $2.7-3.5$ & 13 \\
\hline \multicolumn{9}{|c|}{ Micro-/Nanostructured p-Si } \\
\hline $\mathrm{EL}$ & >10 min@ rt & 100 & 2 & 0.16 & 7.3 & 18 & 21 & 18 \\
\hline EL & $1 \mathrm{~min} @ \mathrm{rt}$ & 100 & 0 & $\sim 0.40$ & 28 & $-d$ & $-d$ & 19 \\
\hline EL & $3 \times 3$ min@rt & 100 & 1 & 0.28 & 23 & 28 & 1.8 & 20 \\
\hline ALD & $\begin{array}{l}50 \text { cycles } \\
@ 250^{\circ} \mathrm{C}\end{array}$ & 100 & 1 & 0.31 & 9 & 55 & 1.5 & 20 \\
\hline EL & 3 min@rt & 100 & 1 & 0.42 & 18 & $-d$ & $-d$ & 22 \\
\hline EL & 10-20min@rt & 100 & 1 & $\sim 0.40$ & $20-25$ & $-d$ & $-d$ & 23 \\
\hline \multicolumn{9}{|c|}{ Planar $^{+} p-S i$} \\
\hline EBE & $\begin{array}{c}\sim 6 \times 10^{-6} \text { torr } \\
\text { pressure }\end{array}$ & 100 & 2 & 0.56 & 28 & 60 & $\sim 10.0$ & 18 \\
\hline \multicolumn{9}{|c|}{ Microwires $n^{+} p-S i$} \\
\hline EBE & $\begin{array}{c}\sim 6 \times 10^{-6} \text { torr } \\
\text { pressure }\end{array}$ & 100 & 2 & 0.54 & 15 & 71 & $\sim 6.0$ & 18 \\
\hline
\end{tabular}

${ }^{a}$ EBE: electron-beam evaporation; EL: electroless; Echem: electrochemistry; ALD: atomic layer deposition. ${ }^{b}$ Vs $\mathrm{Ag} / \mathrm{AgCl} .{ }^{c}$ Measured at different illumination powers from 10 to $100 \mathrm{~mW} \mathrm{~cm}{ }^{-2} .{ }^{d}$ Not indicated. ${ }^{e}$ Conversion efficiency for a complete water splitting photoelectrode device. ${ }^{f}$ Vs SCE; Pt was deposited by passing $\sim 30 \mathrm{mC} \mathrm{cm}^{-2}$ 
of cathodic charge. ${ }^{g}$ 632.8-nm light. ${ }^{h}$ Calculated from photocurrent values and the 3-mm diameter of the photoelectrode.

4. Conclusions. In this work, Pt-metallized silicon photoelectrodes, highly active for HER were fabricated by using the cost effective electroless deposition method by galvanic displacement. It was demonstrated that the morphology, the particle size and the surface distribution could be finely tuned by controlling the metal deposition temperature and time. Isolated Pt structures were produced at all investigated temperatures for short deposition times, typically within $1-10 \mathrm{~min}$ if the temperature was $45^{\circ} \mathrm{C}$ or less than $5 \mathrm{~min}$ at $75^{\circ} \mathrm{C}$. The formation of multifaceted isolated Pt islands and nanotrenches into the silicon bulk were found to be beneficial for improving the catalytic performance of the photoelectrodes for HER. In contrast, the HER performance strongly decreased for photoelectrodes incorporating a high Pt loading with interconnected dendritic structures. The best catalytic performance was obtained for a photoelectrode which had been previously metallized at $45^{\circ} \mathrm{C}$ for $5 \mathrm{~min}$. Such a photoelectrode was highly active for HER at $\mathrm{pH} 1$ with outstanding output characteristics $(F F=45 \%, \eta=9.7 \%$ and $\left|J_{\mathrm{sc}}\right|=15.5 \mathrm{~mA} \mathrm{~cm}^{-2}$ ) under a light illumination of $33 \mathrm{~mW} \mathrm{~cm}$. Such performances could be even improved by using Si structured surfaces incorporating an additional $\mathrm{n}^{+} \mathrm{Si}$ layer on the $\mathrm{p}-$ type Si surface of the photocathode structure. Work directed towards this stimulating prospect is currently underway in our laboratory.

Supporting Information. Additional SEM images and total reflectance spectra of Pt-coated photoelectrodes. This material is available free of charge via the Internet at http://pubs.acs.org. 


\section{AUTHOR INFORMATION}

\section{Corresponding Author}

*E-mail: bruno.fabre@univ-rennes1.fr (B.F.). Tel: +33 (0) 223236 550. Fax: +33 (0) 223236 797.

*E-mail: gabriel.loget@univ-rennes1.fr (G. L.)

\section{Author Contributions}

B. Fabre and G. Loget designed research, analyzed the electrochemical data and wrote the paper.

L. Gaozeng performed research. F. Gouttefangeas and L. Joanny performed the SEM characterizations and analyzed the SEM data. All authors have given approval to the final version of the manuscript.

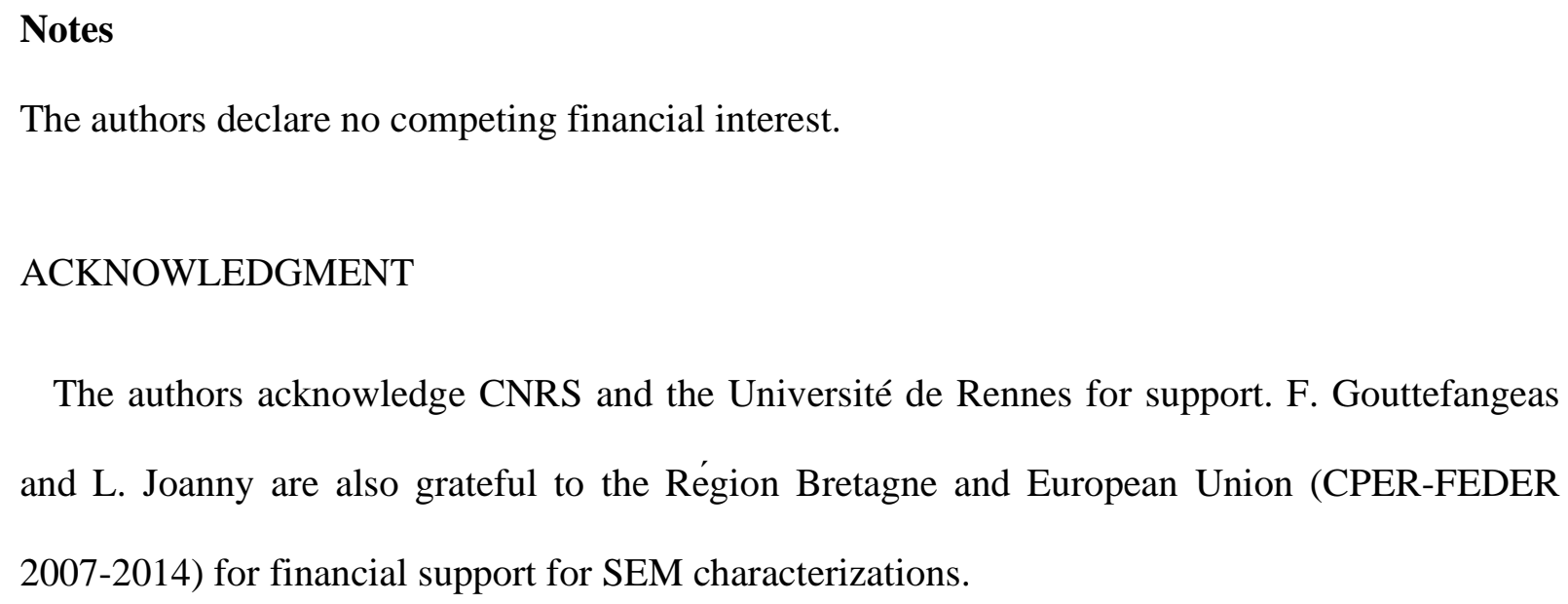

The authors declare no competing financial interest.

\section{ACKNOWLEDGMENT}

The authors acknowledge CNRS and the Université de Rennes for support. F. Gouttefangeas and L. Joanny are also grateful to the Région Bretagne and European Union (CPER-FEDER 2007-2014) for financial support for SEM characterizations. 
Table of Contents Graphic
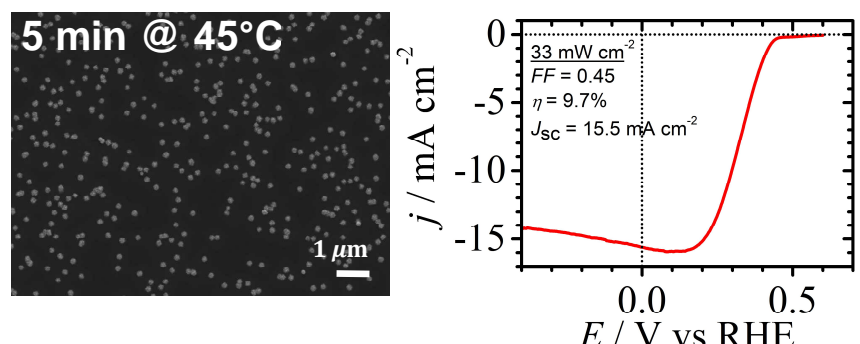

19

E / V vs RHE 


\section{REFERENCES}

(1) Cook, T. R.; Dogutan, D. K.; Reece, S. Y.; Surendranath, Y.; Teets, T. S.; Nocera, D. C. Solar Energy Supply and Storage for the Legacy and Nonlegacy Worlds. Chem. Rev. 2010, 110, 6474-6502.

(2) Lewis, N. S.; Nocera, D. G. Powering the Planet: Chemical Challenges in Solar Energy Utilization. Proc.Natl.Acad.Sci.USA $2006,103,15729-15735$.

(3) Sivula, K.; van de Krol, R. Semiconducting Materials for Photoelectrochemical Energy Conversion. Nat. Rev. Mater. 2016, 1, 1-16.

(4) Kang, D.; Kim, T. W.; Kubota, S. R.; Cardiel, A. C.; Cha, H. G.; Choi, K.-S. Electrochemical Synthesis of Photoelectrodes and Catalysts for Use in Solar Water Splitting. Chem. Rev. 2015, $115,12839-12887$.

(5) Walter, M. G.; Warren, E. L.; McKone, J. R.; Boettcher, S. W.; Mi, Q.; Santori, E. A.; Lewis, N. S. Solar Water Splitting Cells. Chem.Rev. 2010, 110, 6446-6473.

(6) Huang, Q.; Ye, Z.; Xiao, X. Recent Progress in Photocathodes for Hydrogen Evolution. J. Mater. Chem.A 2015, 3, 15824-15837.

(7) Weber, M. F.; Dignam, M. J. Splitting Water with Semiconducting Photoelectrodes-Efficiency Considerations. Int. J. Hvdrogen Energv 1986, 11, 225-232.

(8) Zhang, X. G. In Electrochemistry of Silicon and its Oxide. Kluwer Academic Publishers: New York, 2004.

(9) Sun, K.; Shen, S.; Liang, Y.; Burrows, P. E.; Mao, S. S.; Wang, D. Enabling Silicon for Solar-Fuel Production. Chem.Rev. 2014, 114, 8662-8719. 
(10) Wrighton, M. S. Thermodynamics and Kinetics Associated with Semiconductor Based Photoelectrochemical Cells for the Conversion of Light to Chemical Energy. Pure Appl. Chem. 1985, 57, 57-68.

(11) Morales-Guio, C. G.; Hu, X. Amorphous Molybdenum Sulfides as Hydrogen Evolution Catalysts. Acc. Chem.Res. 2014, 47, 2671-2681.

(12) Hou, Y.; Abrams, B. L.; Vesborg, P. C. K.; Björketun, M. E.; Herbst, K.; Bech, L.; Setti, A. M.; Damsgaard, C. D.; Pedersen, T.; Hansen, O.; Rossmeisl, J.; Dahl, S.; Norskov, J. K.; Chorkendorff, I. Bioinspired Molecular Co-Catalysts Bonded to a Silicon Photocathode for Solar Hydrogen Evolution. Nature Mater. 2011, 10, 434-438.

(13) Dominey, R. N.; Lewis, N. S.; Bruce, J. A.; Bookbinder, D. C.; Wrighton, M. S. Improvement of Photoelectrochemical Hydrogen Generation by Surface Modification of p-Type Silicon Semiconductor Photocathodes. L.Am.Chem.Soc. 1982, 104, 467-482.

(14) Szklarczyk, M.; Bockris, J. O. M. Photoelectrocatalysis and Electrocatalysis on p-Silicon. J. Phvs. Chem. 1984, 88, 1808-1815.

(15) Lombardi, I.; Marchionna, S.; Zangari, G.; Pizzini, S. Effect of Pt Particle Size and Distribution on Photoelectrochemical Hydrogen Evolution by $\mathrm{p}-\mathrm{Si}$ Photocathodes. Langmuir 2007, 23, 12413-12420.

(16) Huang, Z.; McKone, J. R.; Xiang, C.; Grimm, R. L.; Warren, E. L.; Spurgeon, J. M.; Lewerenz, H.-J.; Brunschwig, B. S.; Lewis, N. S. Comparison between the Measured and Modeled Hydrogen-Evolution Activity of $\mathrm{Ni}$ - or Pt-coated Silicon Photocathodes. Int. J. Hvdrogen Energy 2014, 39, 16220-16226. 
(17) McKone, J. R.; Warren, E. L.; Bierman, M. J.; Boettcher, S. W.; Brunschwig, B. S.; Lewis, N. S.; Gray, H. B. Evaluation of Pt, Ni and Ni-Mo Electrocatalysts for Hydrogen Evolution on Crystalline Si Electrodes. Enerov Environ.SCi. 2011, 4, 3573-3583.

(18) Boettcher, S. W.; Warren, E. L.; Putnam, M. C.; Santori, E. A.; Turner-Evans, D.; Kelzenberg, M. D.; Walter, M. G.; McKone, J. R.; Brunschwig, B. S.; Atwater, H. A.; Lewis, N. S. Photoelectrochemical Hydrogen Evolution Using Si Microwire Arrays. J. Am. Chem. Soc. 2011, 133, 1216-1219.

(19) Zhao, Y.; Anderson, N. C.; Zhu, K.; Aguiar, J. A.; Seabold, J. A.; van de Lagemaat, J.; Branz, H. M.; Neale, N. R. Oxidatively Stable Nanoporous Silicon Photocathodes with Enhanced Onset Voltage for Photoelectrochemical Proton Reduction. Nano Lett. 2015, 15, 2517-2525.

(20) Dai, P.; Xie, J.; Mayer, M. T.; Yang, X.; Zhan, J.; Wang, D. Solar Hydrogen Generation by Silicon Nanowires Modified with Platinum Nanoparticle Catalysts by Atomic Layer Deposition. Anoew. Chem.Int.Ed. 2013, 52, 11119-11123.

(21) Qiao, L.; Zhou, M.; Li, Y.; Zhang, A.; Deng, J.; Liao, M.; Xiao, P.; Zhang, Y.; Zhang, S. Enhancing Electrochemical Hydrogen Generation by Platinum-Modification of p-Type Silicon Wires Array under Visible Light. J. Electrochem. Soc. 2014, 161, H458-H463.

(22) Oh, I.; Kye, J.; Hwang, S. Enhanced Photoelectrochemical Hydrogen Production from Silicon Nanowire Array Photocathode. Nano Lett. 2012, 12, 298-302.

(23) Ji, J.; Zhang, H.; Qiu, Y.; Wang, Y.; Luo, Y.; Hu, L. Platinum Nanoparticle Decorated Silicon Nanowire Arrays for Photoelectrochemical Hydrogen Production. J. Mater. Sci. Mater. Electron. 2013, 24, 4433-4438.

(24) Burda, C.; Chen, X.; Narayanan, R.; El-Sayed, M. A. Chemistry and Properties of Nanocrystals of Different Shapes. Chem.Rev. 2005, 105, 1025-1102. 
(25) Somorjai, G. A. Surface Science and Catalysis. Science 1985, 227, 902-908.

(26) Ahmadi, T. S.; Wang, Z. L.; Green, T. C.; Henglein, A.; El-Sayed, M. A. Shape-Controlled Synthesis of Colloidal Platinum Nanoparticles. Science 1996, 272, 1924-1925.

(27) Ahmadi, T. S.; Wang, Z. L.; Green, T. C.; Henglein, A.; El-Sayed, M. A. "Cubic" Colloidal Platinum Nanoparticles. Chem.Mater. 1996, 8, 1161-1163.

(28) Xia, Y.; Xiong, Y. J.; Skrabalak, S. E. Shape-Controlled Synthesis of Metal Nanocrystals: Simple Chemistry Meets Complex Physics ? Angew. Chem. Int. Ed. 2009, 48, 60-103.

(29) Chen, J.; Lim, B.; Lee, E. P.; Xia, Y. Shape-Controlled Synthesis of Platinum Nanocrystals for Catalytic and Electrocatalytic Applications. Nano Todav 2009, 4, 81-95.

(30) Tao, A. R.; Habas, S.; Yang, P. Shape Control of Colloidal Metal Nanocrystals. Small 2008, 4, 310-325.

(31) Tian, N.; Zhou, Z.-Y.; Sun, S.-G.; Ding, Y.; Wang, Z. L. Synthesis of Tetrahexahedral Platinum Nanocrystals with High-Index Facets and High Electro-Oxidation Activity. Science 2007, 316, 732-735.

(32) Tian, N.; Zhou, Z.-Y.; Sun, S.-G. Platinum Metal Catalysts of High-Index Surfaces: From Single-Crystal Planes to Electrochemically Shape-Controlled Nanoparticles. J. Phys. Chem. C 2008, 112, 19801-19817.

(33) Huang, X.; Zhao, Z.; Fan, J.; Tan, Y.; Zheng, N. Amine-Assisted Synthesis of Concave Polyhedral Platinum Nanocrystals Having \{411\} High-Index Facets. J. Am. Chem. Soc. 2011, $133,4718-4721$.

(34) Narayanan, R.; El-Sayed, M. A. Changing Catalytic Activity during Colloidal Platinum Nanocatalysis Due to Shape Changes: Electron-Transfer Reaction. J. Am. Chem. Soc. 2004, 126, 7194-7195. 
(35) Fu, X.; Wang, Y.; Wu, N.; Gui, L.; Tang, Y. Shape-Selective Preparation and Properties of Oxalate-Stabilized Pt Colloid. Langmuir 2002, 18, 4619-4624.

(36) Kinge, S.; Bonnemann, H. One-Pot Dual Size- and Shape Selective Synthesis of Tetrahedral Pt Nanoparticles. Appl. Organomet. Chem. 2006, 20, 784-787.

(37) Zhang, J.; Yao, W.; Liu, M.; Xu, Q.; Wu, Q.; Zeng, T. Shape Controlled Synthesis of Platinum Nanocrystals with High Catalytic Activities for Methanol Electrooxidation. Catal. Lett. 2013, 143, 1030-1034.

(38) Gong, H.; Sun, S.-G.; Chen, Y.-J.; Chen, S.-P. In Situ Microscope FTIRS Studies of CO Adsorption on an Individually Addressable Array of Nanostructured Pt Microelectrodes - An Approach of Combinatorial Analysis of Anomalous IR Properties. J. Phys. Chem. B 2004, 108, $11575-11584$.

(39) Wei, L.; Zhou, Z.-Y.; Chen, S.-P.; Xu, C.-D.; Su, D.; Schuster, M. E.; Sun, S.-G. Electrochemically Shape-Controlled Synthesis in Deep Eutectic Solvents: Triambic Icosahedral Platinum Nanocrystals with High-Index Facets and Their Enhanced Catalytic Activity. Chem. Commun. 2013, 49, 11152-11154.

(40) Li, Y.; Jiang, Y.; Chen, M.; Liao, H.; Huang, R.; Zhou, Z.; Tian, N.; Chen, S.; Sun S. Electrochemically Shape-Controlled Synthesis of Trapezohedral Platinum Nanocrystals with High Electrocatalytic Activity. Chem. Commun. 2012, 48, 9531-9533.

(41) Wei, L.; Fan, Y.-J.; Tian, N.; Zhou, Z.-Y.; Zhao, X.-Q.; Mao, B.-W.; Sun, S.-G. Electrochemically Shape-Controlled Synthesis in Deep Eutectic Solvents-A New Route to Prepare Pt Nanocrystals Enclosed by High-Index Facets with High Catalytic Activity. J. Phys. Chem. C 2012, 116, 2040-2044. 
(42) Carraro, C.; Maboudian, R.; Magagnin, L. Metallization and Nanostructuring of Semiconductor Surfaces by Galvanic Displacement Processes. Surf Sci.Rep. 2007, 62, 499-525. (43) Zhang, X.; Qiao, Y.; Xu, L.; Buriak, J. M. Constructing Metal-Based Structures on Nanopatterned Etched Silicon. ACS Nano 2011, 5, 5015-5024.

(44) Quan, Z.; Wang, Y.; Fang, J. High-Index Faceted Noble Metal Nanocrystals. Acc. Chem. Res. 2012, 46, 191-202.

(45) Loget, G.; Padilha, J. C.; Martini, E. A.; de Souza, M. O.; de Souza, R. F. Efficiency and Stability of Transition Metal Electrocatalysts for the Hydrogen Evolution Reaction using Ionic Liquids as Electrolytes. Int.J.Hudrogen Energy 2009, 34, 84-90. 